\title{
THE EFFECT OF GRAIN REFINING OF PRIMARY SILICON ON THE FLUIDITY OF Al-Si CASTING ALLOYS
}

\author{
Adefuye O.A \\ Department of Mechanical Engineering \\ Lagos State University, Epe, Lagos State, Nigeria \\ Fadipe O.L \\ Department of Mechanical Engineering \\ Lagos State University, Epe, Lagos State, Nigeria
}

\author{
Adedeji K.A \\ Department of Mechanical Engineering \\ Lagos State University, Epe, Lagos State, Nigeria \\ Orisaleye J.I \\ Department of Mechanical Engineering \\ University of Lagos, Akoka, Lagos State, Nigeria
}

\begin{abstract}
Aluminium-silicon alloys possess high mechanical strength to density ratio which makes it suitable for wide engineering applications. Fluidity affects the properties of the alloys. Silicon increases the fluidity of Al-Si alloys. The refinement of silicon alloys improves the mechanical property of the alloys. This study investigated the fluidity of nineteen Al-Si alloys made with silicon of $99.999 \%$ purity and aluminum of $99.999 \%$ purity. A straight channels mold was utilized in determining the fluidity. The casting modulus of the channels varied between $0.2 \mathrm{~mm}$ and $2.9 \mathrm{~mm}$. Using the same quality of materials, a primary silicon refiner Al-Cu-P was added to the alloys. The result was an unexpected $40 \%$ increase in fluidity for the $\mathrm{Al}-8 \% \mathrm{Si}$ alloy. A decrease in fluidity from $35 \%$ to $10 \%$ was observed in the fluidity of the hyper-eutectic alloys.
\end{abstract}

Keywords: Fluidity, casting, grain-refinement, solidification

\section{INTRODUCTION}

Aluminium-silicon (Al-Si) alloys constitute more than $80 \%$ of aluminium casting alloys because of the properties they exhibit. These include high fluidity, high resistance to corrosion, good weldability, reduction in shrinkage and low coefficient of thermal expansion $[9,18]$. The characteristic property of aluminium alloys is the relatively high strength in relation to density. The aluminum-silicon alloys generally have silicon content between $0.5 \%$ and $20 \%$. The importance of Al-Si alloys lies much in their mechanical strength which is developed by grain-refinement of their primary phase or by the modification of their eutectic structure.

Casting fluidity (or simply fluidity) measures in some manner the ability of liquid alloy to fill a mold. This is important to casting as it should specify whether or not a material is suitable for producing a casting based on the shape and dimensions of the casting only. Niu et al. [13] noted that fluidity has a significant influence on the mechanical properties. Insufficient fluidity could result in defects such as incomplete fill or cold shuts in castings which are responsible for degradation of mechanical properties.

The properties of an alloy are attributed to the individual physical properties of its main constituents. Silicon, though very cheap as a raw material, increases the fluidity of the melt, reduces melting temperature, and decreases the contraction associated with solidification $[2,9]$. One of the reasons for the high fluidity has been attributed to the high heat of fusion of primary silicon which is 4.5 times higher than the heat of fusion of pure aluminium [8]. According to Hedge and Prabhu [8], refinement of primary aluminium, silicon and eutectic mixture improves the mechanical properties. Vijeesh and Prabhu [18] noted that hypereutectic alloys are generally treated with phosphorous to refine the primary silicon. Robles Hernandez et al. [16] described the primary Si phase in Al-Si hypereutectic alloys and proposed aspects for its proper refinement.

Birol [3] carried out an investigation of the effect of silicon content in grain refining hypoeutectic $\mathrm{Al}-\mathrm{Si}$ alloys with boron and titanium additions. Zuo et al. [19] and Mina et al. [12] investigated the use of Al-Si-P master alloy in refining primary $\mathrm{Si}$ in hypereutectic A390 alloys. Lee et al. [10] studied the effect of increasing the amount of added grain refiner on grain size and morphology for a range of hypoeutectic Al-Si alloys.

This paper aims to investigate the difference between the fluidity of pure metal and alloys in the Al-Si system and the fluidity of the same metal or alloys when it has been grain refined by the addition of a suitable grain refiner using very pure materials. It 


\section{International Journal of Engineering Applied Sciences and Technology, 2021 Vol. 5, Issue 9, ISSN No. 2455-2143, Pages 71-75 \\ Published Online January 2021 in IJEAST (http://www.ijeast.com)}

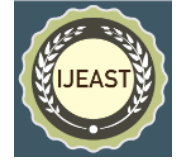

also aims to represent the different types of $\mathrm{Al}-\mathrm{Si}$ casting alloys on the phase diagram adequately.

\section{THEORY}

Fluidity indicates how well a liquid metal or alloy will fill a mold cavity on casting [17]. It is generally defined as the length through which a liquid metal or alloy will flow in a standard fluidity test channel before being arrested by solidification. It is different from, and longer than continuous fluidity, which is the length a liquid metal will fill before solidification starts [5-6]. The mode of solidification may be the most important factor affecting fluidity. Solidification of very pure metals progresses by uniform advancement of plane solidification front from the walls of the test channel to the liquid. Flow is arrested when the plane solidification fronts from all the sides of the wall meet [14]. For an alloy with low solute content, solidification front is rough. Columnar dendrites from the walls of the channels grow into the liquid. Dendrites from opposite sides of the wall grow into each other to form a solid mesh. The flow of the liquid metal is arrested when the permeability of the solid mesh is sufficiently low to prevent flow of the liquid alloy through it. In alloys with a high solute content and in which nucleation is not difficult, solidification starts by nucleation of equiaxed dendrites [7]. The number of the dendrites increases with progress in solidification. When the volume of the dendrites is sufficiently high the flow is arrested.

The pouring temperature also affects the fluidity, the higher the superheat the longer the fluidity. Fluidity has generally been found to increase with decrease in solidification temperature range [15]. However, this has not been true of Al-Si alloys as the eutectic does not have a higher fluidity than the other alloys in the Al-Si system. Turbulence in the flow of the liquid metal or alloy reduces its fluidity. Clean melting and pouring practices improves fluidity. The metal head affects the metals and alloys differently. Increase in metal head increase the fluidity in pure metals and solute rich alloys.

The strength of Al-Si alloys is improved by additives that refine the primary phase. Addition of phosphorous (a refiner of primary silicon) have been shown to decrease the fluidity of hypereutectic Al-Si alloys while the fluidity of hypo-eutectic alloys were shown to be increased by the addition of $\mathrm{TiB}_{2}$ (a primary aluminum grain refiner) $[4,18]$.

\section{EXPERIMENTAL METHOD}

Two sets of experiments were performed. Experiments were conducted to determine the fluidity of pure Al-Si alloys. The other set of experiments was conducted to determine the fluidity of $\mathrm{Al}-\mathrm{Si}$ alloys to which $\mathrm{Al}-\mathrm{Cu}-\mathrm{P}$ (a primary silicon nucleant) were added.
For the preparation of the alloys, the percentage content of aluminum in the ingots was at least $99.999 \%$. The percentage of silicon content in the silicon used to prepare the alloys was 99.9999\%. The $\mathrm{Al}-\mathrm{Cu}-\mathrm{P}$ used for the grain refinement of silicon was made up of $19 \%$ by weight of copper, $1.4 \%$ of phosphorous and $79.9 \%$ of aluminum

To determine the base-line fluidity values, the alloys were melted in an electromagnetic induction furnace (E.M.A.) and poured at $750^{\circ} \mathrm{C}$ through a cup filter and an offset weir basin into the multichannel fluidity test mold. Figure 1 illustrates the pattern used to prepare the fluidity test mold. Each test channel was $504 \mathrm{~mm}$ long and $20 \mathrm{~mm}$ wide. The depths of the channels were $1 \mathrm{~mm}$, $2 \mathrm{~mm}, 3 \mathrm{~mm}$, and $4 \mathrm{~mm}$.

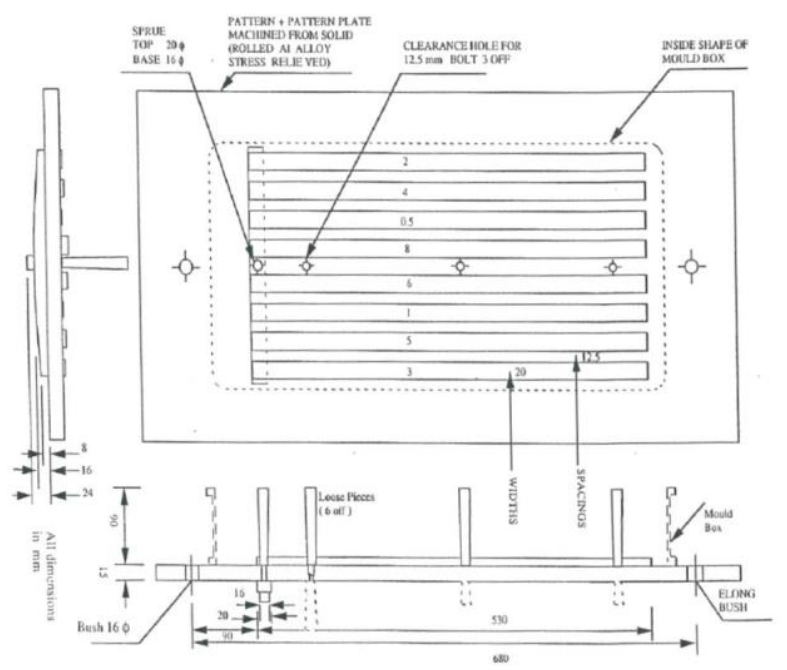

Figure 1: The pattern for the fluidity test mold

The mold was prepared with silica sand of grain size $60 \#$ and 'pepset' was used as the binder. A preheated graphite plunger was used to plug the sprue entrance and was not removed until the basin was full. The alloys that were investigated had silicon content of $0.0,0.5,1.0,1.5,2.0,4.0,6.0,8.0,10.0,11.0,12.0$, $13.0,14.0,15.0,16.0,17.0,18.0,19.0$ and $20.0 \%$ by weight.

In this study, fluidity is defined as the volume of the test strip divided by the cross-sectional area. The casting modulus is defined as the cross-sectional area of the test-channel divided by its perimeter.

Macroscopic and microscopic investigation including the preparation of macroscopic montage of selected strips was carried out. Particle analysis of the primary phase and x-ray investigation of the test strips were also undertaken. 


\section{International Journal of Engineering Applied Sciences and Technology, 2021 \\ Vol. 5, Issue 9, ISSN No. 2455-2143, Pages 71-75 \\ Published Online January 2021 in IJEAST (http://www.ijeast.com)}

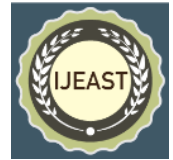

\section{RESULTS AND DISCUSSION}

The composition of alloys to which $\mathrm{Al}-\mathrm{Cu}-\mathrm{P}$ was added is given by Table 1 . The fluidity of untreated Al-Si alloys is illustrated in Figure 2. Pure aluminum is the most fluid material. It filled all the fluidity test channels except the $0.48 \mathrm{~mm}$ modulus channel. Its fluidity in the filled channels could not be determined by the test. The high fluidity of the metal may be attributed to its mode of solidification.

Table 1: Detailed composition of alloys to which Al-Cu-P was added

\begin{tabular}{lcccc}
\hline Alloy & \multicolumn{4}{c}{ Composition (by \%weight) } \\
\cline { 2 - 5 } & $\mathrm{Al}$ & \multicolumn{1}{c}{$\mathrm{Si}$} & $\mathrm{Cu}$ & $\mathrm{P}$ \\
\hline $\mathrm{Al}-6 \% \mathrm{Si}$ & 93.94 & 6.00 & 0.056 & 0.004 \\
$\mathrm{Al}-8 \% \mathrm{Si}$ & 91.94 & 8.00 & 0.056 & 0.004 \\
$\mathrm{Al}-8 \% \mathrm{Si}$ & 91.96 & 7.98 & 0.056 & 0.004 \\
$\mathrm{Al}-11 \% \mathrm{Si}$ & 88.95 & 10.99 & 0.056 & 0.004 \\
$\mathrm{Al}-14 \% \mathrm{Si}$ & 85.95 & 13.99 & 0.056 & 0.004 \\
$\mathrm{Al}-16 \% \mathrm{Si}$ & 83,98 & 15.96 & 0.056 & 0.004 \\
$\mathrm{Al}-18 \% \mathrm{Si}$ & 81.95 & 17.99 & 0.056 & 0.004 \\
\hline
\end{tabular}

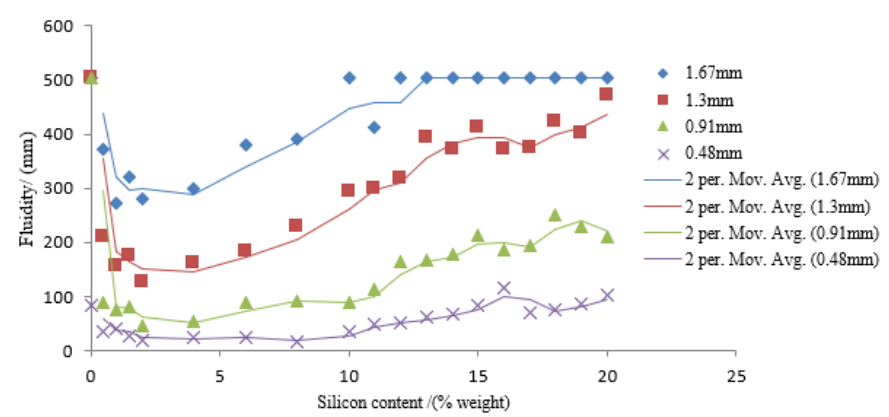

Figure 2: Fluidity as a function of silicon content and test channel modulus

It has been shown from metallographic studies and print of x-ray diffraction mottles that the flow of pure aluminum in the fluidity channels was arrested by growth of planar solidification front. The flow of the solid solution alloys and the hypo-eutectic alloys was arrested by the presence of equiaxed aluminum dendrites near the tip of the test strips. The flow of the eutectic and the hyper-eutectic alloys was arrested by the presence of critical amount of eutectic cells near the tip of the test strip [1].

The fluidity test channel with a modulus of $1.67 \mathrm{~mm}$ was completely filled by alloys with silicon content of $12 \%$ and above. The higher fluidity of the near eutectic and the hypereutectic alloys was as a result of the latent heat of fusion the silicon liberated during the solidification of these alloys. The fluidity of the Al-Si alloys to which Al-Cu-P was added is illustrated by Figure 3. The effect of Al-Cu-P addition on the increase or change in fluidity of the alloys is illustrated by Figure 4.

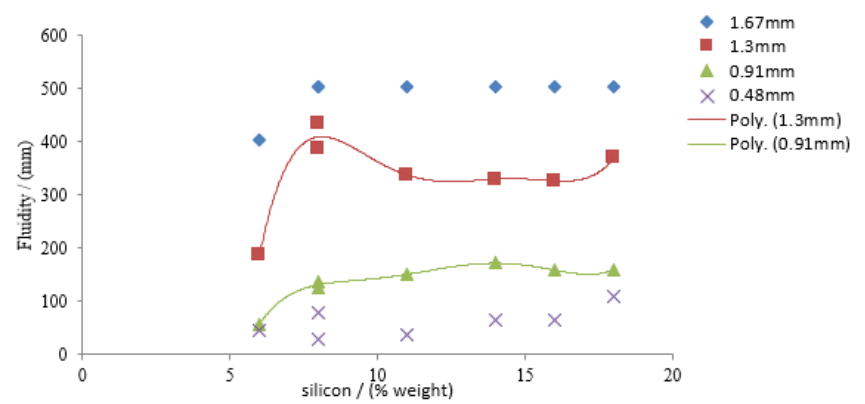

Figure 3: Fluidity of Al-Si alloys treated with $\mathrm{Al}-\mathrm{Cu}-\mathrm{P}$ as a function of silicon content and channel modulus

The fluidity of Al-6\% Si alloy was not affected by addition of Al$\mathrm{Cu}-\mathrm{P}$. This was expected of all hypo-eutectic alloys as primary silicon does not take part in the flow arrest mechanism of these alloys. The high effect of $\mathrm{Al}-\mathrm{Cu}-\mathrm{P}$ on the fluidity of $\mathrm{Al}-8 \% \mathrm{Si}$ alloy, an increase of $80 \%$ and $40 \%$ in $1.3 \mathrm{~mm}$ and $0.91 \mathrm{~mm}$ modulus channel respectively was unexpected. The experiment was repeated and the result was confirmed. The investigations carried out in this work yielded no reason for the increase in fluidity.

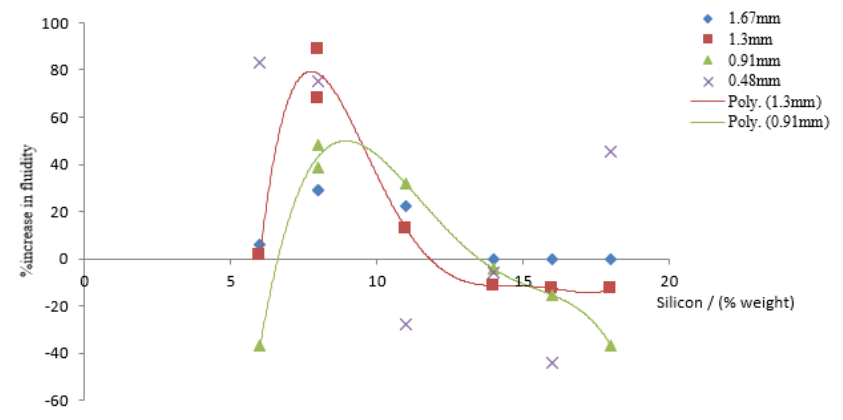

Figure 4: Change in fluidity (due to addition of $\mathrm{Al}-\mathrm{Cu}-\mathrm{P}$ ) as a function of silicon content and channel modulus

In the $1.3 \mathrm{~mm}$ modulus channel, a virtually constant decrease of $12 \%$ was observed in the fluidity of the hyper-eutectic alloys. In the $0.91 \mathrm{~mm}$ modulus channel, a decrease in fluidity ranging from $6 \%$ at a silicon content of $14 \%$ (by weight) to $36.5 \%$ at a silicon content of $18 \%$ (by weight). The decrease in the fluidity of the hyper-eutectic alloys grain refined with $\mathrm{Al}-\mathrm{Cu}-\mathrm{P}$ may be attributed to a change in solidification mechanism from arrest by a critical volume of eutectic cells to a silicon dam mechanism earlier proposed by Mc Parland [11]. 


\section{International Journal of Engineering Applied Sciences and Technology, 2021 \\ Vol. 5, Issue 9, ISSN No. 2455-2143, Pages 71-75 \\ Published Online January 2021 in IJEAST (http://www.ijeast.com)}

The silicon dam is illustrated by Figures 5 and 6 . Once the silicon dam is in place, it filters the liquid passing allowing only progressively finer silicon to pass through accumulating debris of larger silicon partials at the dam. A point is reached when the accumulated silicon particles block the flow path and arrest the flow. The silicon dam arrests the flow faster than the presence of critical volume of either silicon particles or eutectic cells, hence the decrease in fluidity.

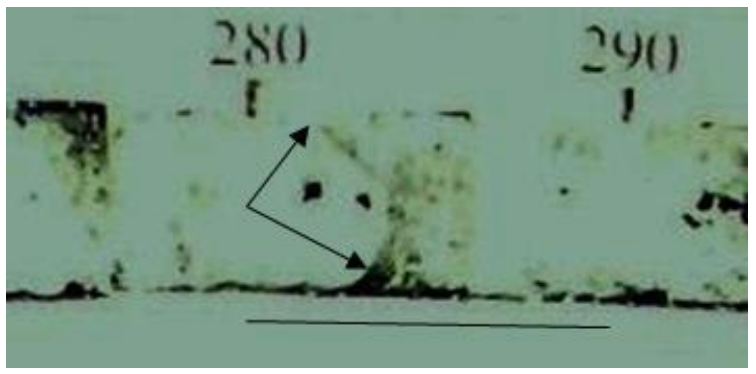

Figure 5: Section of a macro graphic montage of the $\mathrm{Al}-16 \% \mathrm{Si}$ alloy fluidity test strip for the $1.3 \mathrm{~mm}$ modulus channel showing the silicon dam between $280 \mathrm{~mm}$ and $290 \mathrm{~mm}$ from the channel inlet (The arrows point to the silicon dam. The line scale length is $10 \mathrm{~mm}$ ).

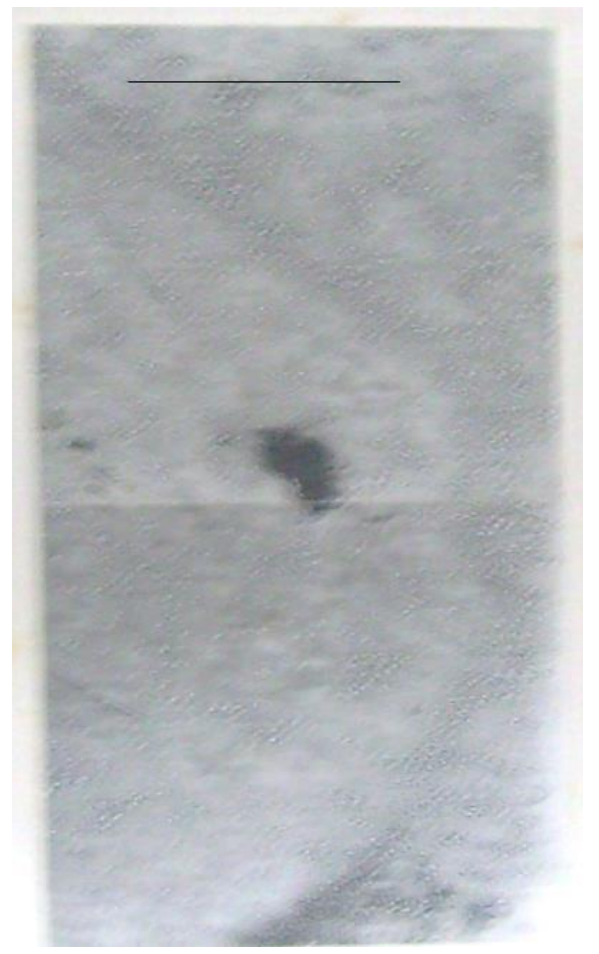

Figure 6: The silicon dam at a higher magnification (The line scale represents $1 \mathrm{~mm}$ ).

\section{CONCLUSION}

A suitable base line fluidity data for Al-Si casting alloys with adequate representation of all types of alloys on the $\mathrm{Al}-\mathrm{Si}$ system was generated. The addition of $\mathrm{Al}-\mathrm{Cu}-\mathrm{P}$ to the $\mathrm{Al}-8 \% \mathrm{Si}$ increased the fluidity of the alloy significantly. In the $1.43 \mathrm{~mm}$ modulus channel the fluidity was increased by $80 \%$ and in the $0.91 \mathrm{~mm}$ modulus channel the fluidity was increased by $40 \%$.

In the hyper-eutectic alloys, the addition of $\mathrm{Al}-\mathrm{Cu}-\mathrm{P}$ changed the mechanism of flow arrest from the presence of a critical volume of the eutectic cells to the arrest of flow by silicon dam mechanism. This caused a reduction of fluidity by a virtually constant value of $12 \%$ in the $1.3 \mathrm{~mm}$ modulus channel and by between $6 \%$ and $36.5 \%$ in the $0.91 \mathrm{~mm}$ modulus channel.

\section{ACKNOWLEDGEMENT}

This author wishes to thank the Association of Commonwealth Universities (ACU) and Professor John Campbell and the casting group Centre for the Development of Materials for high technical application and Cadbury Bourneville Birmingham U.K. for sponsoring this work. Thank you,

\section{REFERENCES}

[1] Adefuye, O. A. (2006). The effect of sodium modification of the eutectic structure on the fluidity of Al-Si alloys. In: Proceedings Materials Science and Technology Conference, October 15-19, 2006, Cincinnati, Ohio, USA.

[2] Adefuye, O. A. (2014). Casting fluidity of commercially pure Al-Si casting alloys. Transactional Journal of Science and Technology, 4(1):16-30.

[3] Birol, Y. (2012a). Effect of silicon content in grain refining hypoeutectic $\mathrm{Al}-\mathrm{Si}$ foundry alloys with boron and titanium additions. Materials Science and Technology, 28(4):385-389.

[4] Birol, Y. (2012b). Performance of AlTi5B1, AlTi3B3 and AlB3 master alloys in refining grain structure of aluminium foundry alloys. Material Science and Technology, 28(4):481-486.

[5] Campbell, J. (1995). Review of fluidity concepts in casting. Cast Metals, 7(4):227-237.

[6] Campbell, J. (2003). Castings. Elsevier.

[7] Di Sabatino, M. (2005). Fluidity of aluminium foundry alloys. PhD Thesis, Norwegian University of Science and Technology (NTNU), Trondheim.

[8] Di Sabatino, M. and Arnberg, L. (2004). A review on the fluidity of Al based alloys. Metallurgical Science and Technology, 22(1):9-15. 
[9] Hedge, S. and Prabhu, K. N. (2008). Modification of eutectic silicon in Al-Si alloys. Journal of Materials Science, 43(9):3009-3027.

[10] Lee, Y. C., Dahle, A. K., StJohn, D. H. and Hutt, J. E. C. (1999). The effect of grain refinement and silicon content on grain formation in hypoeutectic Al-Si alloys. Materials Science and Engineering: A, 259(1):43-52.

[11] Mc Parland, A. J. (1987). The fluidity and flow property of aluminium melts. Ph.D. Thesis, University of Sheffield.

[12] Mina, Z.., Liu, X., Dai, H. and Liu, X. (2009). Al-Si-P master alloy and its modification and refinement performance on Al-Si alloys. Rare Metals, 28(4):412417.

[13] Niu, G., Mao, J. and Wang, J. (2019). Effect of Ce addition on fluidity of casting aluminum alloy A356, Metallurgical and Materials Transactions A, 50(12):5935-5944.

[14] Piwonka, T. S. (1998). Solidification of metal and alloys. In: Metals Handbook Desk Edition, Second Edition, (Ed: Davis, J. R.), ASM International.

[15] Ravi, K. R., Pillai, R. M., Amaranathan, K. R., Pai. B. C. and Chakraborty, M. (2008). Fluidity of aluminium alloys and composites: a review. Journal of Alloys and Compounds, 456(1-2):201-210.

[16] Robles Hernandez F.C., Herrera Ramírez J.M., Mackay R. (2017) Grain Refinement. In: Al-Si Alloys. Springer, Cham.

[17] Spittle, J. A. (2006). Grain refinement in shape casting of aluminium alloys. International Journal of Cast Metals Research, 19(4):210-222.

[18] Vijeesh, V. K. and Prabhu, N. (2014). Review of microstructure evolution in hypereutectic $\mathrm{Al}-\mathrm{Si}$ alloys and its effect on wear properties. Transactions of the Indian Institute of Metals, 67(1):1-18.

[19] Zuo, M., Liu, X. F., Sun, Q. Q. and Jiang, K. (2009). Effect of rapid solidification on the microstructure and refining performance of an Al-Si-P master alloy. Journal of Materials Processing Technology, 209(15-16):55045508 . 